\title{
Designing Campaign of Blue Light Hazard for Teenager in Bandung
}

\author{
Azmil Ibrahim Aziz ${ }^{1}$, Muhammad Hidayattuloh ${ }^{2}$, \\ ${ }^{1}$ Visual Communication Design, Telkom University, Bandung, Indonesia \\ ${ }^{2}$ Visual Communication Design, Telkom University, Bandung, Indonesia \\ azmi176@gmail.com (Azmil Ibrahim Aziz), hidayattuloh@tcis.telkomuniversity.ac.id (M. Hidayattuloh)
}

\begin{abstract}
Eyes is one of the most important part belonged to the human body. Eyes became one of the important organ because it can represent a figure. But many people forget to pay attention to the health of their eyes. Using gadgets without regard for the dangers that are present in every gadget, i.e. Blue Light. Using the gadget should be limited to maintain eye health. Qualitative methods then found a way to deliver the information on time use of the gadgets are safe is through the design of media campaigns to provide information about a safe time in using the gadget. The media can be an event, new media, website to notify secure in using the gadgets, and other supporters of the print media.
\end{abstract}

Keywords Blue Light, Event, Eye Health, Gadgets, Social Campaigns, Teens.

\section{Introduction}

Bandung has become one of the largest population cities in Indonesia. According to the Badan Pusat Statistik (BPS) of West Java, Bandung has a population of 2.47 million and there are approximately 438 thousand citizens in school age. As one of the city's dense population, the progress of Bandung is also very rapidly. Progress of Bandung, one in the field of technology. The technology is very beneficial because it can facilitate the work of man. In addition, according to the National Youth Committee (KNPI) in Indonesia site mentions one of the programs of Bandung City Mayor, Ridwan Kamil was wanted to make Bandung as the smart city at the end of 2017 which is supported by the community of Bandung city.

In an era of increasingly sophisticated digital all the things can be obtained easily from the information, education, and entertainment. The convenience can be obtained even with just one tool, namely smart phones or Smartphones that are already considered as basic needs for most people, especially those living in big cities. High rates of use of smartphone unwittingly giving effect that may harm the eye, i.e. the Blue Ray. Blue light emitted by all digital devices that have a screen, one of which is a smartphone. Based on data from site A Healthier Michigan in its website, the Department of Health and Human Services U.S. set secure electronic screen looked at time is 2 hours per-day. However, as is known, the reliance of modern humans with technology and electronic devices are difficult to be separated because it is the main requirement. Whereas the excessive use of smartphones can be bad for eye health which is one of the main five senses of man. The eye became one of the principal organs as it can represent a way.

Teenager is the most interesting period. One of the teen's characteristic is less wait until they're not thinking about what will happen next as long as his desire is achieved. Teens don't know what is right and wrong as long as there is nothing to guide them towards the right path until many of them overboard in doing things without know the dangers and the effects that would be experienced in the future.

From these problems, the authors conclude that in every electronic item that emits light, there is a blue light (blue light) which is very dangerous for eye health. Seeing the potential danger posed, it is unfortunate that many teenagers who are dependent with smartphones to potentially experience blindness in the future. For that, it is necessary to hold a campaign to inform and invite teenagers in Bandung to play the gadget safely given the difficulty of releasing human dependence with his gadgets. Seeing the phenomenon the authors are interested in designing blue light hazard campaign for teenager in Bandung

\section{Theoretical Background}

Venus (2012:7) in his book concludes that the campaign is essentially an act of persuasion that invites or encourages audiences to accept or do something on the basis of volunteerism. Because of its nature, a campaign volunteer who was there need be no coercion in an attempt to influence the public. Refer to the definition above, any campaign activity 
should at least have four aspects including (1) the Act of a campaign that is intended to create a specific impact or effect (2) a large number of target audience (3) usually concentrated in a certain period of time and (4) through a series of organized communication actions.

Surbakti (2011:2) in his book States that teenager is a community consisting of a group of men and women who are starting from $12-14$ years up to $19-20$ years. A group of teenagers is a community transition from children toward adulthood. From the sources mentioned above, the author has an opinion that the teenager was the time that someone started to look for and recognize her as a whole as a human being and started to train yourself to live independently.

Visual communication design is the art of conveying information or messages by using visual language / visual which is conveyed through the media in the form of design. Visual Communication design aims to inform, influence, to change the behavior of the target (audience) in accordance with the goals that want to be realized (Anggraini and Nathalia, 2014: 15)

\section{The Research Method}

The method used in this design is qualitative with direct observation of the object under study, interviews with related parties, questionnaires with questions some of which are addressed by target targets, literature studies and field research methods related issues.

\section{Result and Discussion}

The main problem of the teens and the smartphone is the lack of concern about their eye health and environmental conditions around. Most of the teenagers in Bandung using smartphones more than 5 hours a day. But according to the Department of Health and Human Services U.S. smartphone usage limits should not be more than 2 hours per day. In addition to inflicting harm on eye health, using excessive smartphone also impacted badly on the social conditions of youth. Teenagers are supposed to be active more often silent and preoccupied with their smartphones.

Then, the author makes a conclusion that need to be made a campaign educating teenagers in Bandung, about the dangers of Blue Light. Based on the nature of an active teenager, the author decided to create an event in a teenager learns about the dangers of Blue Light. The event is expected to touch on the rational side of teenagers in learning new knowledge about the dangers of Blue Light.

Therefore, based on the nature of the active teen and they desire to continue socializing should be utilized in making a campaign educating rationally.
The campaign was supported by some other media in addition to the event, including posters, social media, microsite, ambient media, and gimmik. The poster is useful in the campaign blue light hazard and promotes the event to be held. Social media is one of the media that is often used by teenagers. In social media, there will be some information about the dangers of blue light and the event. Just as social media, microsite is also used in support of audiences to get the needed information. Ambient media used to interest a wider audience about the campaign. Ambient media is a vending machines. Inside it, there are games that are related to the impact of the Blue Light.

The media are organized in accordance with media strategies that have been create. In this design, promotion using AISAS media strategy (Attention, Interest, Action, Share). With this promotion is expected Happy Fresh can increase users and can expand the target audience.

Table 1. Campaign Media Table

\begin{tabular}{|c|c|c|c}
\hline Campaign Phase & $\begin{array}{c}\text { AISAS } \\
\text { Model }\end{array}$ & Attributes & Media \\
\hline $\begin{array}{c}\text { Cognitive State } \\
\text { (Conditioning) }\end{array}$ & Attention & Passive & $\begin{array}{c}\text { Print Ad } \\
\text { Social Media } \\
\text { Microsite }\end{array}$ \\
\hline \multirow{2}{*}{$\begin{array}{c}\text { Affective Stage } \\
\text { (Informing) }\end{array}$} & Interest & Active & $\begin{array}{c}\text { Ambient } \\
\text { Microsite } \\
\text { Social Media } \\
\text { Print Ad }\end{array}$ \\
\cline { 2 - 4 } & Search & Active & $\begin{array}{c}\text { Microsite } \\
\text { Social media } \\
\text { Ambient }\end{array}$ \\
\hline \multirow{2}{*}{$\begin{array}{c}\text { Behavioral Stage } \\
\text { (Reminding) }\end{array}$} & Action & Active & \begin{tabular}{c} 
Event \\
Microsite \\
\cline { 2 - 4 }
\end{tabular} \\
\cline { 2 - 4 } & Share & Active & $\begin{array}{c}\text { Social Media } \\
\text { Gimmick }\end{array}$ \\
\hline
\end{tabular}

\section{Conclusion}

The campaign of blue light hazard for teenager in Bandung is utilizing the nature of active teens to educate them about the message of this campaign. The authors hope the campaign can educate teenagers about the dangers of blue light rationally and slowly change the habit of playing smartphone with more wisdom. 


\section{ACKNOWLEDGEMENTS}

The author wants to give appreciation to teenager in Bandung who are willing to become the object of design and also the lecturer who help the author to finish this journal.

\section{REFERENCES}

[1] Anggraini S., Lia, dan Kirana Nathalia. 2014. Desain Komunikasi Visual; Dasar-dasar Panduan untuk Pemula. Jakarta: Nuansa Cendekia.

[2] Surbakti, E. B. 2011. Question \& Answer Teenagers. Jakarta: PT. Elex Media Komputindo.

[3] Venus, Antar. 2004. Manajemen Kampanye. Bandung: Simbiosa Rekatama Media. 